\author{
전통 장류로 제조한 양념육의 숙성 중 맛성분 변화 \\ 하경희 $*$ 주선태**. 박구부**. 성낙주 $* * *$. 류현지* 박기훈****. 김일석****. 진상근**** \\ 농촌진흥청 축산연구소*, 경상대학교 동물자원과학부**, 경상대학교 식품영양학과***, \\ 진주산업대학교 동물소재공학과****
}

\title{
Changes in Taste Compounds of Seasoned Pork with Korean Traditional Sauces during Aging
}

\author{
K. H. Hah*, S. T. Joo**, G. B. Park**, N. J. Sung***, H. J. Lyou*, K. H. Park****, I. S. Kim**** \\ and S. K. Jin****
}

National Livestock Research Institute*, Division of Animal Science, Gyeongsang National University**, Department of Food and Nutrition, Gyeongsang National University***, Department of Animal Resources Technology, Jinju National University****

\begin{abstract}
This study was carried out to evaluate changes in taste compounds of seasoned pork with Korean traditional sauces. The samples, pork loins were cut by the shape of cube $(5 \times 15 \times 5 \mathrm{~cm})$ and seasoned pork with Korean traditional sauces such as soy sauce base (T1), red pepper sauce base (T2), and soybean sauce base (T3) in the same proportion of meat seasonings, respectively. The seasoned samples were stored, at $1 \pm 1{ }^{\circ} \mathrm{C}$ during 28 days. Citric acid and fumaric acid were higher after 14 days of storage for the treatments, seasoned pork with red pepper sauce had higher compared to other treatments. While propionic acid and lactic acid were higher in seasoned pork with soybean sauce compared to other treatments. Free amino acids was higher in seasoned pork with soybean and red pepper sauce compared to seasoned pork with soy sauce. In all treatments, free amino acids was slightly increased with aging periods. 5'-inosine monophosphate (IMP) was decreased, whereas inosine was increased with increase of aging time. Inosine was higher in seasoned pork with soybean and red pepper sauce compared to seasoned pork with soy sauce. In sensory evaluation, aroma, flavor, tenderness and juiciness were increased with aging period increased in all treatments.
\end{abstract}

(Key words : Taste compound, Korean traditional sauce, 5'-inosine monophosphate, Inosine)

\section{I. 서 론}

식품가공의 목적은 편리성과 기호성이 가장 중요한 요소로서 인식되고 있으며 가공 중 첨 가되는 조미료는 기호성 향상과 밀접한 관계가 있으나, 최근 식생활 수준의 향상으로 인공조 미료를 기피하고 천연조미료를 추구하는 경향 으로 바뀌고 있다. 조미.향신료들은 단순히
음식의 맛을 좋게 해 줄 뿐만 아니라 발효 식 품의 숙성을 조절하고 식품의 조직감과 질감의 향상, 식품의 보존성 향상 그리고 나쁜 냄새와 결합하여 나쁜 맛을 억제시키거나 없애주는 등 의 역할을 한다. 우리가 이용하는 조미.향신 료의 종류는 대단히 많으며 세계 각 곳에서는 지역 풍토에 맞게 이들을 각각 효과적으로 이 용해 왔다. 조미.향신료의 식품 과학적인 효

Corresponding author:S. K. Jin, Department of Animal Resources Technology, Jinju National University, Jinju, 660-758, Korea. Tel : 82-55-751-3283, Fax : 82-55-758-1892, E-mail : skjin@jinju.ac.kr 
과는 이들이 가지고 있는 특유한 방향 성분들 로 식욕을 촉진시킬 수 있으며, 음식에 첨가되 었을 때 음식의 성분과 복합미를 형성하여 맛 성분을 유도할 수 있고 나쁜 맛을 함유하거나 조리 시에 발생되는 나쁜 맛 성분의 약화, 억 제 혹은 소멸시키는 작용이 있다. 또한 식품의 조리, 가공, 저장 시에 이들 성분이 발효를 조 절하는 작용과 항균력이 있어 어떤 성분은 발 효를 촉진하고 어떤 성분은 억제하는 효과가 있으며, 산화방지 효과도 지닌다(손, 1990).

양념육에 많이 사용되는 조미료인 양파, 생 강, 마늘 등의 향신료와 향신료의 정유가 세균 포자의 내열성에 현저한 영향을 주며, 이들이 지방의 산화효소의 작용을 억제한다(문과 최, 1986)고 알려져 있다. 또한 조미료의 성분들이 생체조직내의 효소활성을 억제시키거나 항균, 항산화 작용, 유산균 증식작용, 항동맥경화, 혈 액응고 방지 등의 작용이 있다고 보고되었다 (서, 1973; 이, 1974; Cavallito 등, 1945; 강과 장, 1983).

우리나라의 대표적 발효식품인 간장과 된장 은 영양상 단백질의 좋은 공급원일 뿐 아니라 조미료로서 중요한 역할을 하므로 대두는 상당 한 비율이 발효식품인 장류제조에 이용되고 있 다. 간장이나 된장의 고유한 맛은 소금에서 오 는 짠맛, 탄수화물이나 덱스트린이 가수분해 되어 생긴 당의 단맛과 단백질의 가수분해산물 인 아미노산에서 오는 구수한 맛 등이 적절히 조화된 전 세계 어떠한 향신료나 음식과도 조 화가 잘 되며 우리 식탁에서도 빠지지 않는 음 식의 재료이다. 최근 이러한 전통 장류를 이용 한 양념육에 관한 논문들이 꾸준히 발표되고 있으나 맛성분과 관련된 연구가 거의 이루어지 지 않아 본 연구에서는 전통장류를 이용한 양 념육을 제조하여 숙성하는 동안 양념육의 맛성 분 변화를 측정하였다.

\section{II. 재료 및 방법}

\section{1. 공시재료 및 양념 배합비}

돼지를 도축 후 24 시간 냉각된 지육 중에서
농림부가 고시한 가공기준에 준하여 등심을 채 취하여 과다한 지방을 제거하였다. 준비한 시 료들을 $5 \times 15 \times 5 \mathrm{~cm}$ 크기로 자른 후 Table 1 과 같이 개발된 배합비에 따라 간장, 고추장, 된장 양념육을 각각 제조하여 플라스틱 박스에 넣은 후 $1 \pm 1{ }^{\circ} \mathrm{C}$ 에서 28 일간 저장하면서 실험 재료로 공시하였다.

Table 1. Recipes of seasoned pork

(Unit : \%)

\begin{tabular}{lccc}
\hline \multirow{2}{*}{ Ingredients } & \multicolumn{3}{c}{ Treatments $^{1)}$} \\
\cline { 2 - 4 } & $\mathrm{T} 1$ & $\mathrm{~T} 2$ & $\mathrm{~T} 3$ \\
\hline \hline Pork & 50 & 50 & 50 \\
Soy sauce & 11 & & \\
Red pepper paste & & 21.5 & - \\
Raw soybean paste & & - & 15 \\
Ground onion & 5 & - & 5 \\
Ground radish & 2.5 & - & 4.5 \\
Ground garlic & 3.5 & 3 & 4 \\
Ground ginger & 1 & - & 1 \\
Corn syrup & 16 & 11.5 & 11.5 \\
Water & 11 & 14 & 9 \\
\hline Total & 100 & 100 & 100 \\
\hline
\end{tabular}

${ }^{1)} \mathrm{T} 1$ : Seasoned pork with soy sauce base, T2: Seasoned pork with red pepper sauce base, T3: Seasoned pork with soybean sauce base. Salinity : 2.5 , saccharinity : 30 .

\section{2. 실험방법}

(1) 유기산

시료 $50 \mathrm{~g}$ 에 증류수 $50 \mathrm{~mL}$ 를 가하여 1 분간 균질기(IKA, T25 Basic, Malaysia)로 분쇄한 다 음 여과지(Whatman No. 2)와 membrane filter (Milipore, $0.45 \mu \mathrm{m}$ )로 여과시킨 후 Sep pak $\mathrm{C}_{18}$ (Waters Inc., USA) cartridge를 통과시켜 HPLC (Agilent 1100 series, Germany)에서 다음의 조건 하에서 정량하였다. Column은 Aminex HPX-87H, 용매는 $0.05 \mathrm{M} \mathrm{H} \mathrm{H}_{2} \mathrm{SO}_{4}$, flow rate $1.0 \mathrm{~mL} / \mathrm{min}$, detector는 UV $210 \mathrm{~nm}$ 를 사용하였다.

(2) 유리아미노산

시료 $5 \mathrm{~g}$ 에 $70 \%$ ethanol $50 \mathrm{~mL}$ 를 가하여 homo- 
genizer(IKA, T25 Basic, Malaysia)로 10,000 rpm 에서 30 초간 균질화한 후 $3,000 \mathrm{rpm}$ 에서 20 분간 원심분리 하였다. 상층액을 취하고 침전물은 앞의 과정을 한 번 더 수행하여 그 상층액을 앞의 상층액과 합하여 진공농축하고 $10 \mathrm{~mL}$ 로 조절하였다. 여기에 perchloric $\operatorname{acid}(\mathrm{PCA}) 5 \mathrm{~g}$ 을 가하여 교반 후 30 분간 방치하고 $5,000 \mathrm{rpm}$ 에서 20 분간 원심분리 하였다. 상층액을 $0.45 \mu \mathrm{m} \mathrm{mem-}$ brane filter로 여과한 다음 시료로 사용하였다. 유리아미노산의 분석은 자동아미노산 분석기 (SYKAM, S433 A.A., Germany)로 실시하였으며 분석 조건은 column size $4 \times 150 \mathrm{~mm}$, resin $\mathrm{Li}$ form, lithium citrate buffer(pH 2.20), 유속은 0.45 $\mathrm{mL} / \mathrm{min}$, ninhydrin은 $0.25 \mathrm{~mL} / \mathrm{min}$ 의 조건으로 분석하였다.

\section{(3) 핵산관련물질}

시료 $10 \mathrm{~g}$ 에 $10 \% \mathrm{PCA}$ (perchloric acid) $25 \mathrm{~mL}$ 를 가하여 차게 유지하면서 균질화(IKA, T25 Basic, Malaysia)한 뒤 원심분리(4,000 rpm/10분) 하여 상층액만 모으고 잔사는 같은 방법으로 2 회 반복 처리하였다. 상층액을 모아 $5 \mathrm{~N} \mathrm{KOH}$ 용액으로 $\mathrm{pH}$ 6.5로 조절한 후 $100 \mathrm{~mL}$ 가 되게 정량하였다. 이를 약 30 분 방치한 후 10,000 $\mathrm{rpm}$ 에서 $10 \mathrm{~min}$ 원심분리하고 membrane filter (Milipore, $0.45 \mu \mathrm{m}$ )로 여과하고 Sep pak $\mathrm{C}_{18}$ cartridge를 사용하여 단백질, 지방산, 색소 등을 제거한 후 HPLC(Agilent 1100 series, Germany) 에서 다음과 같은 조건으로 정량하였다. Column 은 Waters $\mu$-Bondapak $\mathrm{C}_{18}$, 용매는 $\mathrm{Na}_{2} \mathrm{SO}_{4} 60 \mathrm{~g}$ $+\mathrm{NH}_{4} \mathrm{H}_{2} \mathrm{PO}_{4} 1.36 \mathrm{~g} / 1,000 \mathrm{ml} \quad$ D.W, $1.0 \mathrm{~mL} / \mathrm{min}$, detector는 UV(254 nm)를 사용하였다.

(4) 관능검사

관능검사는 잘 훈련된 관능검사요원 10 명을 선발하여 각 시험구별로 9점 척도법을 실시하 였으며 향, 풍미, 다즙성, 연도, 전체적 기호도 항목으로 관능검사를 실시하였다.

\section{3. 통계처리}

이상의 실험에서 얻어진 결과는 $\mathrm{SAS}(1999)$ 프로그램을 이용하여 분산분석을 수행하였고,
Duncan의 multiple range test로 5\% 수준에서 평 균 간의 유의성을 검정하였다.

\section{III. 결과 및 고찰}

\section{1. 유기산}

Fig. 1은 전통장류를 이용하여 제조한 양념육 을 숙성하는 동안 유기산 함량의 변화를 나타 낸 것이다. Citric acid는 숙성 1일에 비해 14일 째에 유의적으로 $(\mathrm{p}<0.05)$ 로 증가하였으나 그 이 후에는 큰 변화를 나타내지 않았으며, T2 처리 구가 다른 처리구에 비해 높은 함량을 나타내 었다. 이는 $\mathrm{T} 2$ 처리구 양념의 주가 되었던 고 추장이 콩과 쌀을 주 원료로 하여 제조되는데 콩에 존재하는 총 유기산 중 citric acid는 70 $80 \%$ 를 차지하며 쌀에서도 그 함량이 높기 때 문에(전 등, 1995) T2의 citric acid가 다른 처리 구에 비해 높게 나타난 것으로 사료된다. 또한 TCA cycle에서 생성되는 citric acid는 탈지대두 와 소맥의 전량을 코오지로 만들어 담근 간장 에서는 숙성과정 중 현저히 감소하나(전 등, 1995), 콩이나 쌀의 일부만을 코오지로 만들어 담근 된장이나 고추장에서는 그 함량이 높다 (이 등, 1981)고 하였는데 본 실험에서는 $\mathrm{T} 3$ 처 리구의 citric acid는 낮게 나타났다. 고린내의 성분으로 추정되는 propionic acid는 숙성 초기 에 비해 숙성 말에 증가하였는데, $\mathrm{T} 3$ 처리구가 다른 처리구에 비해 높은 값을 나타내었으며 $(\mathrm{p}<0.05), 2 \sim 3$ 개의 미지 물질도 검출되었다. 일 반적으로 propionic acid는 개량식 장에서 숙성 기간에 따라 감소한다고 하였는데 본 실험에서 는 증가하는 것으로 나타났다. 콩, 쌀 등의 원 료에는 미량으로 존재하나 숙성과정 중 미생물 대사 작용이나 발효에 의해 생성된 유기산으로 알려져 있는(전 등, 1995) lactic acid는 T3 처리 구가 숙성 1 일 높게 나타났으나, 숙성 14일 부 터는 다른 처리구와 같은 경향을 나타내었고, 숙성기간에 따른 변화는 나타내지 않았다. 처 리구들에서 숙성초기 유기산 함량은 lactic acid, propionic acid, citric acid, fumaric acid 순이었으 나, 숙성 28일에는 propionic acid, lactic acid, 
Fig. 1. Changes in organic acids of seasoned pork with Korean traditional sauces during aging at $1 \pm 1^{\circ} \mathrm{C}$.

T1: Seasoned pork with soy sauce base, T2: Seasoned pork with red pepper sauce base,

T3: Seasoned pork with soybean sauce base.

citric acid, fumaric acid 순으로 낮게 나타났다.

\section{2. 유리아미노산}

Table 2는 전통장류를 이용하여 제조한 양념 육을 숙성하는 동안 유리아미노산 함량의 변화 를 나타낸 것이다. 일반적으로 식육을 숙성할 때 유리아미노산이 증가하며 이로 인해 숙성육 의 풍미가 증가하게 된다(Nishimura 등, 1995). 이는 lysosome으로부터 acid lipase가 많이 유리 되어 지방 가수분해를 촉진하기 때문이며(Geromel 과 Montgomery, 1980), 육 조직으로부터 단백질 이 분해되어 유리아미노산을 생성하고 이들이 숙성과정 중 계속해서 용출되기 때문이라 사료 된다. 본 실험에서는 총 17 종의 유리아미노산 이 동정되었으며, arginine이 가장 많이 검출되 었고, 그 다음으로 threonine, lysine, leucine 등
의 순으로 동정되었다. 또한 모든 항목에서 숙 성기간에 따라 그 함량은 증가하는 경향을 나 타내었으나, 함량의 유의적인 차이는 나타나지 않았다. 처리구들의 유리아미노산은 T2 처리구 가 가장 많이 검출되었으며 $\mathrm{T} 2$ 처리구와 $\mathrm{T} 3$ 처리구의 함량 차이는 크게 나타나지 않았고, 숙성기간 동안 그 경향은 유지되었다. 일반적 으로 상온에서 저장한 염지육이 냉장 온도에서 저장한 염지육에 비해 증가폭이 상대적으로 높 은 경향이 있는데 이것은 지방 산패에 유리 아 미노산이 관여하기 때문(김 등, 1988)이며 이러 한 경우에는 높은 온도에서 장시간 염지는 유 리아미노산의 증가폭은 다소 큰 이점이 있으나 반대로 신선도에 문제가 있는 것으로 사료된 다. 따라서 본 실험에서 숙성기간에 따라 유리 아미노산 함량의 증가폭이 크지 않았던 것은 낮은 온도에서 숙성하였기 때문으로 사료된다. 
Table 2. Changes in free amino acid contents of seasoned pork with Korean traditional sauce during aging at $1 \pm 1^{\circ} \mathrm{C}$

(Unit : $\mathrm{mg} \%)$

\begin{tabular}{|c|c|c|c|c|}
\hline & \multirow{2}{*}{ Treatments ${ }^{1)}$} & \multicolumn{3}{|c|}{ Days } \\
\hline & & 1 & 14 & 28 \\
\hline \multirow{3}{*}{ Glutamic acid } & $\mathrm{T} 1$ & $5.62 \pm 1.99$ & $5.73 \pm 2.16$ & $5.81 \pm 1.29^{b}$ \\
\hline & $\mathrm{T} 2$ & $8.37 \pm 2.07$ & $8.51 \pm 2.20$ & $8.71 \pm 0.59^{\mathrm{a}}$ \\
\hline & $\mathrm{T} 3$ & $8.35 \pm 1.11$ & $8.81 \pm 2.59$ & $8.96 \pm 1.84^{\mathrm{a}}$ \\
\hline \multirow{3}{*}{ Proline } & $\mathrm{T} 1$ & $13.29 \pm 7.67$ & $13.73 \pm 8.41$ & $14.59 \pm 3.22^{\mathrm{a}}$ \\
\hline & $\mathrm{T} 2$ & $8.23 \pm 1.24$ & $8.98 \pm 3.59$ & $8.90 \pm 2.98^{b}$ \\
\hline & $\mathrm{T} 3$ & $7.41 \pm 0.72$ & $8.38 \pm 3.01$ & $8.60 \pm 1.90^{b}$ \\
\hline \multirow{3}{*}{ Glycine } & $\mathrm{T} 1$ & $4.57 \pm 1.28$ & $4.66 \pm 1.40$ & $4.58 \pm 0.26$ \\
\hline & $\mathrm{T} 2$ & $5.35 \pm 0.14$ & $5.22 \pm 1.42$ & $5.18 \pm 0.53$ \\
\hline & $\mathrm{T} 3$ & $4.91 \pm 3.19$ & $4.93 \pm 3.09$ & $5.35 \pm 2.34$ \\
\hline \multirow{3}{*}{ Alanine } & $\mathrm{T} 1$ & $14.80 \pm 12.16$ & $14.97 \pm 5.35$ & $14.80 \pm 6.04$ \\
\hline & $\mathrm{T} 2$ & $15.36 \pm 1.06$ & $15.07 \pm 1.92$ & $15.01 \pm 3.58$ \\
\hline & $\mathrm{T} 3$ & $14.71 \pm 8.12$ & $14.74 \pm 6.18$ & $15.38 \pm 2.02$ \\
\hline \multirow{3}{*}{ Threonine } & $\mathrm{T} 1$ & $23.59 \pm 10.26$ & $23.65 \pm 5.71$ & $23.62 \pm 3.86$ \\
\hline & $\mathrm{T} 2$ & $25.28 \pm 3.46$ & $25.86 \pm 4.36$ & $25.42 \pm 8.49$ \\
\hline & $\mathrm{T} 3$ & $24.74 \pm 2.51$ & $24.93 \pm 12.93$ & $24.83 \pm 0.98$ \\
\hline \multirow{3}{*}{ Serine } & $\mathrm{T} 1$ & $6.76 \pm 4.44$ & $6.89 \pm 4.08$ & $6.76 \pm 2.09$ \\
\hline & $\mathrm{T} 2$ & $7.69 \pm 1.80$ & $7.81 \pm 0.71$ & $7.70 \pm 1.17$ \\
\hline & $\mathrm{T} 3$ & $7.62 \pm 0.88$ & $7.59 \pm 2.53$ & $7.58 \pm 0.94$ \\
\hline \multirow{3}{*}{ Valine } & $\mathrm{T} 1$ & $10.16 \pm 5.87$ & $10.26 \pm 4.15$ & $10.25 \pm 1.34$ \\
\hline & $\mathrm{T} 2$ & $10.47 \pm 1.88$ & $9.87 \pm 0.57$ & $9.97 \pm 1.59$ \\
\hline & $\mathrm{T} 3$ & $9.92 \pm 2.78$ & $9.72 \pm 2.08$ & $10.75 \pm 1.06$ \\
\hline \multirow{3}{*}{ Tyrosine } & $\mathrm{T} 1$ & $9.94 \pm 4.97$ & $9.74 \pm 4.34$ & $9.92 \pm 4.94$ \\
\hline & $\mathrm{T} 2$ & $10.47 \pm 1.72$ & $10.27 \pm 2.60$ & $10.61 \pm 1.53$ \\
\hline & $\mathrm{T} 3$ & $10.45 \pm 4.36$ & $10.10 \pm 2.61$ & $10.08 \pm 1.58$ \\
\hline \multirow{3}{*}{ Phenylalanine } & $\mathrm{T} 1$ & $10.49 \pm 4.87$ & $10.69 \pm 2.05$ & $10.92 \pm 1.75$ \\
\hline & $\mathrm{T} 2$ & $10.70 \pm 4.85$ & $11.47 \pm 1.04$ & $11.77 \pm 2.47$ \\
\hline & $\mathrm{T} 3$ & $11.63 \pm 5.29$ & $11.22 \pm 2.85$ & $11.27 \pm 4.01$ \\
\hline \multirow{3}{*}{ Methionine } & $\mathrm{T} 1$ & $3.48 \pm 1.41$ & $3.67 \pm 0.55$ & $3.71 \pm 0.51$ \\
\hline & $\mathrm{T} 2$ & $3.93 \pm 0.26$ & $4.10 \pm 0.17$ & $4.91 \pm 3.31$ \\
\hline & $\mathrm{T} 3$ & $4.17 \pm 2.12$ & $4.52 \pm 1.74$ & $5.26 \pm 2.02$ \\
\hline
\end{tabular}

1) T1: Seasoned pork with soy sauce base, T2: Seasoned pork with red pepper sauce base, T3: Seasoned pork with soybean sauce base.

a, b Means with different superscripts in the same column are significantly different $(\mathrm{P}<0.05)$. 
Table 2. Continued

(Unit : $\mathrm{mg} \%$ )

\begin{tabular}{|c|c|c|c|c|}
\hline & \multirow{2}{*}{ Treatments $^{1)}$} & \multicolumn{3}{|c|}{ Days } \\
\hline & & 1 & 14 & 28 \\
\hline \multirow{3}{*}{ Isoleucine } & $\mathrm{T} 1$ & $8.13 \pm 2.48$ & $8.20 \pm 3.55$ & $8.16 \pm 1.65$ \\
\hline & $\mathrm{T} 2$ & $8.06 \pm 0.36$ & $8.09 \pm 0.33$ & $8.15 \pm 0.66$ \\
\hline & T3 & $8.01 \pm 1.73$ & $8.03 \pm 3.02$ & $8.03 \pm 1.02$ \\
\hline \multirow{3}{*}{ Leucine } & $\mathrm{T} 1$ & $17.88 \pm 3.02$ & $17.98 \pm 3.84$ & $18.21 \pm 5.09$ \\
\hline & $\mathrm{T} 2$ & $18.03 \pm 3.82$ & $18.03 \pm 0.37$ & $18.24 \pm 1.88$ \\
\hline & $\mathrm{T} 3$ & $17.82 \pm 6.65$ & $18.60 \pm 2.12$ & $19.61 \pm 2.17$ \\
\hline \multirow{3}{*}{ Histidine } & $\mathrm{T} 1$ & $2.42 \pm 1.63$ & $2.47 \pm 0.85$ & $2.59 \pm 0.46$ \\
\hline & $\mathrm{T} 2$ & $3.16 \pm 0.08$ & $3.16 \pm 0.26$ & $3.25 \pm 0.60$ \\
\hline & $\mathrm{T} 3$ & $3.06 \pm 1.75$ & $3.14 \pm 0.70$ & $3.17 \pm 0.27$ \\
\hline \multirow{3}{*}{ Cystine } & $\mathrm{T} 1$ & $7.25 \pm 1.23$ & $8.02 \pm 2.67$ & $8.25 \pm 1.23$ \\
\hline & $\mathrm{T} 2$ & $9.59 \pm 3.68$ & $9.51 \pm 2.64$ & $10.71 \pm 1.77$ \\
\hline & $\mathrm{T} 3$ & $10.01 \pm 4.92$ & $10.43 \pm 4.86$ & $11.44 \pm 4.36$ \\
\hline \multirow{3}{*}{ Asparagine } & $\mathrm{T} 1$ & $0.85 \pm 0.61$ & $0.95 \pm 0.15^{\mathrm{a}}$ & $0.86 \pm 0.25^{\mathrm{a}}$ \\
\hline & $\mathrm{T} 2$ & $0.40 \pm 0.09$ & $0.47 \pm 0.12^{\mathrm{b}}$ & $0.41 \pm 0.09^{b}$ \\
\hline & $\mathrm{T} 3$ & $0.43 \pm 0.07$ & $0.42 \pm 0.10^{\mathrm{b}}$ & $0.39 \pm 0.05^{\mathrm{b}}$ \\
\hline \multirow{3}{*}{ Lysine } & $\mathrm{T} 1$ & $12.94 \pm 4.36$ & $13.04 \pm 4.47$ & $12.92 \pm 1.79$ \\
\hline & $\mathrm{T} 2$ & $19.73 \pm 2.90$ & $19.91 \pm 2.18$ & $18.97 \pm 7.53$ \\
\hline & $\mathrm{T} 3$ & $19.84 \pm 7.95$ & $19.71 \pm 5.25$ & $17.82 \pm 3.35$ \\
\hline \multirow{3}{*}{ Arginine } & $\mathrm{T} 1$ & $46.30 \pm 19.61$ & $46.66 \pm 11.99$ & $46.33 \pm 12.11$ \\
\hline & $\mathrm{T} 2$ & $45.08 \pm 21.53$ & $45.44 \pm 17.45$ & $45.43 \pm 11.33$ \\
\hline & $\mathrm{T} 3$ & $44.00 \pm 20.88$ & $44.06 \pm 14.00$ & $44.69 \pm 9.93$ \\
\hline \multirow{3}{*}{ Total } & $\mathrm{T} 1$ & $198.48 \pm 56.40$ & $201.29 \pm 50.02$ & $202.28 \pm 28.43$ \\
\hline & $\mathrm{T} 2$ & $210.06 \pm 9.22$ & $210.61 \pm 25.28$ & $213.37 \pm 25.48$ \\
\hline & T3 & $207.08 \pm 63.58$ & $209.33 \pm 30.66$ & $213.24 \pm 27.04$ \\
\hline
\end{tabular}

1) T1: Seasoned pork with soy sauce base, T2: Seasoned pork with red pepper sauce base, T3: Seasoned pork with soybean sauce base.

${ }^{\mathrm{a}, \mathrm{b}}$ Means with different superscripts in the same column are significantly different $(\mathrm{P}<0.05)$. 


\section{3. 핵산관련물질}

Fig. 2는 전통장류를 이용하여 제조한 양념육 을 숙성하는 동안 핵산관련물질 함량의 변화를 나타낸 것이다. IMP는 숙성초기에는 높은 값을 나타내었으나 숙성에 의해 그 값이 월등히 감 소하였으며 처리구에 따른 차이는 크게 나타나 지 않았다. $\mathrm{ADP}$ 는 처리구에 의한 차이는 나타 나지 않았으며 숙성 14 일에 모든 처리구에 서 감소하였다가 숙성 28 일 다소 증가하였다. $\mathrm{AMP}$ 는 $\mathrm{T} 1$ 처리구와 $\mathrm{T} 2$ 처리구는 숙성 1 일에 비해 숙성 28 일에 감소하였으며 $\mathrm{T} 3$ 는 숙성기간 에 따른 함량 변화는 나타나지 않았다. T2 처 리구가 숙성 초기에는 그 함량이 높았으나 숙 성기간이 증가함에 따라 그 감소 폭이 크게 나 타났다. Inosine은 숙성 기간에 따라 모든 처리
구에서 증가하였으며, $\mathrm{T} 1$ 처리구는 다른 처리 구에 비해 그 함량도 적었고 증가폭도 작게 나 타났다. 고기의 맛과 관련이 깊은 것으로 알려 진 IMP는 숙성 3 일째 그 함량이 최고조에 달 했으며, 숙성 3 일까지 $\mathrm{ADP}$ 와 $\mathrm{AMP}$ 함량이 급속히 감소하는 것에 기인한다고 하였으며 (Terasaki 등, 1965), 궈(1964)도 돈육에서 IMP 함량이 3일째 가장 높았다고 보고하였는데 본 실험에서는 도축 후 24 시간이 지난 돈육을 이 용하여 양념육을 제조하였기에 숙성 1일에 IMP 함량이 가장 높게 나타난 것으로 판단되 며 숙성기간에 따라 그 함량이 급속히 감소하 였다.

Watanabe 등(1989)은 양고기를 이용한 실험에 서 숙성기간에 따라 IMP는 도살 1 일째 최고 치까지 급속히 증가한 후 점차 감소하였으며,

Fig. 2. Changes in nucleotides related components of seasoned pork with Korean traditional sauces during aging at $1 \pm 1^{\circ} \mathrm{C}$.

T1: Seasoned pork with soy sauce base, T2: Seasoned pork with red pepper sauce base, T3: Seasoned pork with soybean sauce base. 


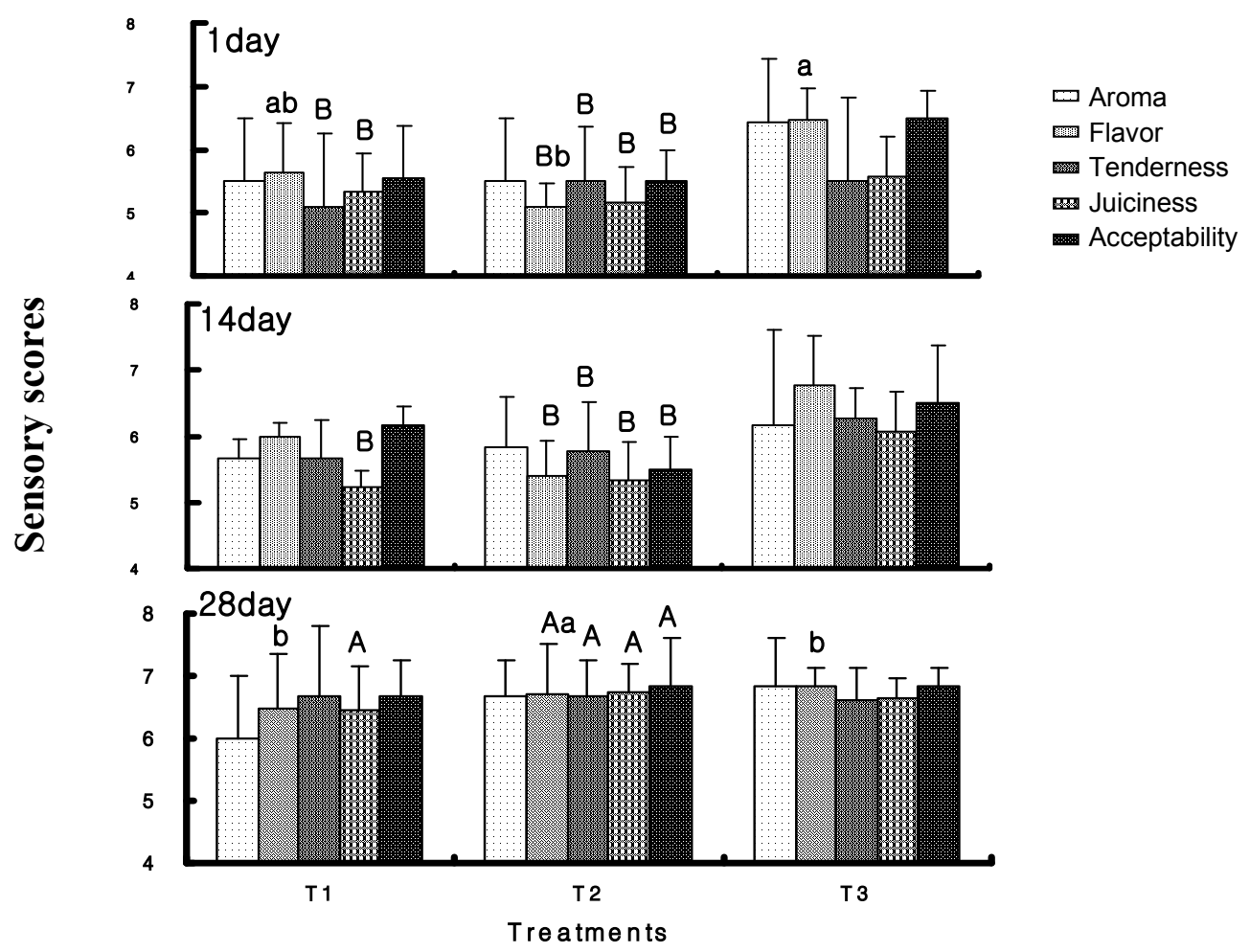

Fig. 3. Changes in sensory evaluation of seasoned pork with Korean traditional sauces during aging at $1 \pm 1^{\circ} \mathrm{C}$.

T1: Seasoned pork with soy sauce base, T2: Seasoned pork with red pepper sauce base,

T3: Seasoned pork with soybean sauce base.

A,B Means with different superscripts within a storage differ $(\mathrm{p}<0.05)$.

${ }^{a, b}$ Means with different superscripts within a treatment differ $(p<0.05)$.

$\mathrm{AMP}$ 는 숙성 10 일째 미세한 감소를 보인 것을 제외하고 전 숙성기간 동안 거의 변하지 않았 다고 보고하였는데, 본 실험에서는 $\mathrm{T} 1$ 처리구 는 숙성 14 일에 그 함량이 감소하였다가 28일 에 다소 증가하였으며 $\mathrm{T} 2$ 처리구는 숙성기간에 따라 그 함량이 감소하였고, $\mathrm{T} 3$ 처리구는 전 숙성기간 동안 그 함량에 큰 변화를 나타내지 않았다. 안과 박(2002)은 한국 토종 닭고기의 정미성분에 대해 보고하였는데 도살 직후 높게 나타났던 $\mathrm{ATP}$ 가 $4{ }^{\circ} \mathrm{C}$ 에서 48 시간 숙성 후에는 완전히 고갈되었으며 IMP의 함량이 가장 높게 나타났다고 하였다. 이러한 ATP의 함량은 가축 의 부위, 품종, 축종에 따라 다르게 나타나며 초기 ATP의 함량에 따라 IMP의 함량도 달라진 다고 하였다.

\section{4. 관능검사}

Fig. 3은 전통장류를 이용하여 제조한 양념육 을 숙성하는 동안 관능검사 결과를 나타낸 것 이다. 본 실험에서는 숙성 1 일 모든 처리구에 서 연도와 다즙성은 낮게 나타났고, $\mathrm{T} 3$ 처리구 는 전체적으로 기호성이 높게 나타난 것을 볼 수 있으며, 이는 향과 맛은 높게 나왔기 때문 으로 사료된다. 따라서 양념육에서는 연도도 중요하지만 향과 풍미가 전체적인 기호성을 좌 우하는 것으로 사료된다. 그리고 숙성기간의 증가에 따라 향과 풍미는 물론 연도와 다즙성 도 증가되어 기호성도 숙성 초기에 비해 증가 되는 것을 볼 수 있는데 $(\mathrm{p}<0.05)$, 이는 숙성 중 단백질 구조의 변화나 이온강도의 변화 등에 
의해서 돈육의 보수력이 회복된 결과로 판단되 며(Wu와 Smith, 1987), 숙성 초기에 처리구들에 따른 연도 차이는 숙성기간이 경과함에 따라 근육 내 단백질 분해효소들에 의한 숙성효과로 처리구들에 따른 차이는 점점 줄어들어 숙성 28일에는 모든 처리구에서 비교적 높은 연도와 다즙성을 유지하였다. 일반적으로 염이 첨가된 육제품에서는 삼투압에 의해 조직 내의 수분이 밖으로 삼출되므로 보수력이 낮아져 다즙성이 떨어지는 것으로 나타나는데 본 실험에서는 숙 성 28일에 연도는 물론 다즙성도 높게 나타났 다.

\section{IV. 요 약}

한국 전통 장류를 이용한 양념 돈육의 맛성 분에 관한 연구로 돼지고기의 등심을 채취하여 $5 \times 15 \times 5 \mathrm{~cm}$ 크기로 자른 후 육을 동일한 비율의 양념액에 침지하여 $1 \pm 1{ }^{\circ} \mathrm{C}$ 에서 28일간 숙성하면 서 양념육(간장소스 양념육, $\mathrm{T} 1$; 고추장소스 양 념육, T2; 된장소스 양념육, T3)의 품질 특성을 조사하였다. Citric acid와 fumaric acid는 숙성 14 일 높게 나타났으며, 고추장소스로 양념한 돈육이 다른 처리구에 비해 높은 함량을 나타 내었다. Propionic acid와 lactic acid는 다른 처리 구에 비해 된장소스로 양념한 돈육에서 높게 나타났다. 유리 아미노산은 간장소스로 양념한 돈육에 비해 된장과 고추장소스로 양념한 돈육 에서 높게 나타났으며, 숙성기간에 따라 모든 처리구에서 약간 증가하였다. 숙성기간동안 IMP 는 감소한 반면, inosine은 증가하였으며, inosine 은 간장소스로 양념한 돈육에 비해 된장과 고 추장소스로 양념한 돈육에서 높게 나타났으며, 숙성기간에 따라 모든 처리구에서 증가하였다. 관능검사는 숙성기간의 증가에 따라 향과 맛은 물론 연도와 다즙성도 증가되어 기호성도 숙성 초기에 비해 증가되었다. 이상의 결과를 요약 해 보면 기존의 양념육은 간장소스가 대부분이 었으나 고추장소스나 된장소스를 활용한다면 맛과 품질이 우수한 다양한 양념육 생산이 가 능할 것으로 사료된다.
$\mathrm{V}$. 사 사

본 연구는 2003년도 한국학술진흥재단(KRF2003-002-F00028)의 연구비 지원에 의하여 이루 어진 것으로 이에 감사를 드립니다.

\section{VI. 인 용 문 헌}

1. Cavallito, C. J., Bailey, J. H. and Buck, J. S. 1945. The Antibacterial principle of Allium Sativum Ill its precursor and "Essential Oil of Garlic.", J. Am. Chem. Soc. 67:1032.

2. Geromel, E. J. and Montgomery, M. W. 1980. Lipase from lysosomes of rainbow trout muscle subjected to low temperature. J. Food Sci. 45:412.

3. Nishimura, T., Hattori, A. and Takahashi, K. 1995. Structural weakening of intramuscular connective tissue during conditioning of beef. Meat Sci. 39:127.

4. SAS. 1999. SAS/STAT Software for PC. Release 8.1, SAS Institute, Cary, NC, U.S.A.

5. Terasaki, M., Kajikawa, M., Fujita, E. and Ishii, K. 1965. Studies on the flavor of meat Part I . Formation and degradation of inosinic acids in meat. Agric. Biol. Chem. 29:208.

6. Watanabe, A., Tsuneeishi, E. and Takimoto, Y. 1989. Analysis of ATP and its break-down products in beef by reversed phase HPLC. J. Food Sci. 54:1169.

7. Wu. F. Y. and Smith S. B. 1987. Ionic strength and myofibrillar protein solubilization. J. Anim. Sci. 65:597.

8. 강신주, 장현숙. 1983. 몇가지 향신료의 항균작 용. 경북대학교 사범대학 논문집. 제 25 집. pp. 133-139.

9. 김영호, 양승용, 이무하. 1988. 동결속도에 따른 우육의 냉동 저장 중 이화학적 변화. 한국식품과 학회지. 20:447.

10. 문갑순, 최홍식. 1986. 우육 지방질의 산화에 미 치는 간장의 항산화 작용에 관한 연구. 한국식품 과학회지. 18:313.

11. 서명자. 1973. 식품 첨가물의 소화 효소의 활성 에 미치는 영향. 한국영양학회지. 6:55.

12. 손경희. 1990. 조미향신료의 식품과학적인 측면. 
한국식문화학회지. 5:391.

13. 안동현, 박소현. 2002. 한국 토종 닭고기의 정미 성분 중 유리아미노산과 핵산관련물질에 대한 연구. 한국식품영양과학회지. 31:547.

14. 이택수, 박성오, 이명환. 1981. 전분질의 원료를 달리한 고추장의 유기산 정량. 한국농화학회지. 24:120.

15. 이희봉. 1974. 한국산 향신료의 항산화 효과에
관한 연구. 충북대학교 논문집. 제 8집. pp. 173176.

16. 전명숙, 이택수, 노봉수. 1995. 담금방법을 달리 한 고추장의 유기산 및 지방산의 변화. 한국식품 과학회지. 27:25.

17. 寺崎. 1964. 畜肉中のイノシン酸の生成. 分解を 中心として.武田りボタイド通信. 24:1.

(접수일자 : 2005. 7. 6./ 채택일자 : 2005. 10. 5.) 